\section{Negative Oxidation-Reduction System of $B$. coli}

STEPHENSON and Stickland $(1931)^{1}$ demonstrated in $B$. coli an enzyme which could catalyse the reduction of methylene blue by molecular hydrogen. Examination of this reduction process discloses a striking resemblance to the hydrogen electrode.

$$
\begin{array}{lll}
\mathrm{H}_{2} & \text { bacteria } & 2 \mathrm{H}+ \\
\mathrm{H}_{2} \stackrel{\text { platinised } \mathrm{Pt}}{\longrightarrow} & 2 e \\
& & 2 \mathrm{H}^{+}+2 e
\end{array}
$$

In other words, the bacterium behaves like a platinised platinum surface in bringing molecular hydrogen into equilibrium with hydrogen ions. We have investigated the reversibility of this reaction of $B$. coli using as an indicator $\gamma \gamma^{\prime}$-dimethyl dipyridyl, the $E_{0}{ }^{\prime}$ of which lies in the range of the hydrogen electrode from $p \mathrm{H} \mathrm{7-9.}$

The reversibility was tested (1) by maintaining the $p \mathrm{H}$ at a constant level and varying the partial pressure of hydrogen, and (2) maintaining the partial pressure constant and varying the $p \mathrm{H}$. The observed potentials agreed well with the theoretical potentials calculated for the hydrogen electrode under identical conditions. This reversible hydrogenase system of $B$. coli is the most negative oxidation-reduction system as yet described in living cells. The complete experimental details will be published shortly.

L. H. STICKLAND.

D. E. GReEv.

\section{Institute of Biochemistry,} Cambridge.

'Stephenson and Stickland, Biochem. J., 25, 205; 1931.

\section{Origin of African House Rats}

Three main types, or mutations, are known of the common house rat: (1) a grey type with grey belly (Rattus rattus rattus, Linnæus), (2) a brown type with grey belly (R. r. alexandrinus, E. Geoffroy), (3) a brown type with a creamy belly $(R$. $r$. frugivorus, Rafinesque).

From an analysis of the distribution of the wild stock it has been possible to show that this wild stock represented by $R$. r. frugivorus originally came from north-west India, the wild race inhabiting the lower Indus Valley being identical with it ; this race is the westernmost of the wild local races of $R$. rattus, and is connected by intermediate types with the other races found in India and Malaya. Rats of the stock developed from this type are common all over Africa, the white-bellied type being imported by coast shipping, and the grey-bellied overland up the Nile Valley so far as Uganda, in the trail of overland traffic, or even earlier with the immigration of the cattle-raising tribes from the north. It has recently been possible to show that in addition to the frugivorus stock, and its mutations, another race of Indian rat has been material in building up the house-rat population of East Africa. Both the wild creambellied (R. r. wroughtoni, Hinton) and a parasitic greybellied mutation (R.r. rufescens, Gray) of the more rufous South Indian rat have been found on Zanzibar Island, in central Kenya, and as far inland as Uganda. They probably came from India by shipping on the Bombay-Goa-Zanzibar track.

The possibility of analysing an introduced rat population appears to be of importance as it is much easier to trace the origin of these rats than that of either man or fleas carrying disease. It will probably be found that the history of the Uganda plague centre can be reconstructed in this way. It looks as if the various types keep separate, and that they differ in their biology. It is not known at present whether the different races and mutations of house rats differ in their susceptibility to or immunity from plague, although certain observations would point in that direction.

ERnst Schwarz.

Zoological Department, British Museum (Natural History). March 9.

\section{An Ancient Foxtail Pine}

My young friend Mr. Allan Caplan has recently obtained a remarkable series of fossil plants in the Miocene shales at Creede, Colorado. Among these the conifers are especially interesting, and one specimen consists of a small cone, about $19 \mathrm{~mm}$. long, broadly oval in form, the scales armed with long prickles (Fig. 1). I sought the advice of my colleague, Dr. Edna L. Johnson, who at once produced some immature cones of Pinus aristata, Engelmann, the foxtail pine of the western mountains of the United States. On comparison, it was impossible to see any difference. Knowlton (1923) described a Pinus crossii from Creede, based on foliage which does not appear to differ from that of $P$. aristata.

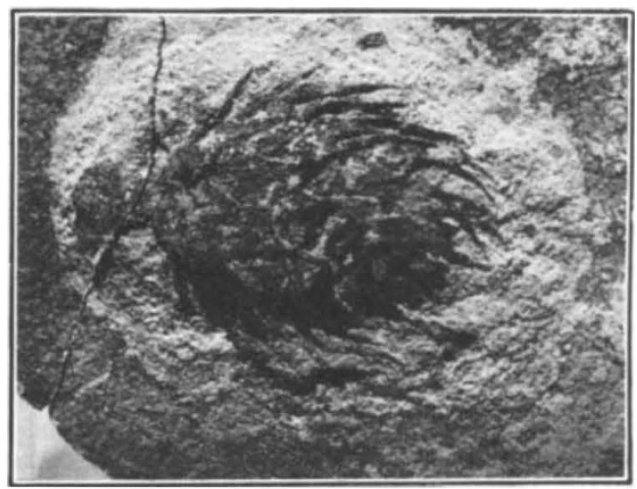

Fic. 1. Cone of Pinus aristata crossii (enlarged). Photograph : Hugo Rodeck.

In common with other writers, I have assumed Miocene species to be distinct from their modern relatives, even when the visible differences were slight, and such as might indicate only a variety or form in the modern flora. Considering the millions of years intervening, it has seemed reasonable to assume that the species would be different, and to suppose that if we had the complete plants, other differences than those recorded would be apparent. What shall we do, however, when there are no visible differences?

In a paper recently received ${ }^{1}$ on the Miocene flora of Oregon, Mr. H. D. MacGinitie proposes a new species, Acer negundoides, based on fruits which he says are "plainly referable to Acer negundo, L." $\mathrm{He}$ not only fails to cite any differential characters for his species, but also expressly states that there are none, so far as the material shows. Similarly, 